\title{
Work in Progress: Assessing Intercultural Competency in an E-learning En- vironment
}

Dr. Jennifer R Amos, University of Illinois, Urbana-Champaign

Dr Amos joined the Bioengineering Department at the University of Illinois in 2009 and is currently a Sr Lecturer and Director of Undergraduate programs. She received her B.S. in Chemical Engineering at Texas Tech and Ph.D. in Chemical Engineering from University of South Carolina. She has developed and offered more than 5 courses since joining the faculty and has taken the lead roll in curriculum development for the department.

Hyun Hannah Choi, University of Illinois, Urbana-Champaign Mr. Kenneth D. Long, University of Illinois, Urbana-Champaign Adam Rusch, University of Illinois, Urbana-Champaign 


\title{
Works in Progress: Assessing Intercultural Competency in an E-learning Environment
}

\begin{abstract}
As the world rapidly progresses toward a complex global community from a collection of independent nation-states, it is increasingly evident that the future of education lies in preparing students to collaborate, communicate, and cooperate in dynamic, multidisciplinary, and multicultural spaces. The development of discipline-based differences, vocabularies, and personalities is nothing new, and as bodies of knowledge continue to grow and increase in complexity, the difficulty of translating across disciplines to address increasingly broader global challenges also increases. Similarly, the need for cultural competency is expanding beyond the number of students realistically supported by traditional study abroad programs. This project utilizes global health as the paradigm within which to pursue a novel e-learning environment in partnership with Njala University to develop this capacity for international interdisciplinary translation.

The program is committed to prepare the engineering global health leaders of tomorrow with sensitivity to globalization, experience with international partnerships, and a mindset of interdisciplinary collaboration. These experiences will be a springboard for increasingly collaborative curricular experiences for our university students to work together to develop competency in intercultural interaction and to engage in sharing their unique perspectives and experiences.

This study aims to measure engineering students' intercultural competence - their ability to participate in a multicultural team-based learning environment effectively - and to determine the effectiveness of curriculum to affect intercultural competency. This effort aims not only to improve the program quality but also to communicate the findings related to curriculum development to establish effective teaching methods with other programs through peer reviewed journal publications and conference presentations.

This study extensively analyzes students' learning progress in intercultural competence. Data involving both quantitative and qualitative methods are used to assess student learning via pre/post surveys and student performance in discussion board activities, reflection assignments, projects. The study emphasizes translating skills between disparate groups, be it a cultural, academic, or physical separation, as fundamental skills for the students of tomorrow.
\end{abstract}

\section{Certificate program design}

Building upon the existing agricultural-based partnership between a the University of Illinois at Urbana-Champaign and a Njala University in Sierra Leone, a new facet was established specifically focused on Global Health.

While significant work on global health-related topics is ongoing across the university, there has not been a concerted effort to collaborate and communicate across departments and colleges. 
Over the past two years, a working group comprised of students and faculty from the colleges of Engineering, Medicine, Applied Health Sciences, Agriculture, Veterinary Medicine, and Business has developed the framework to bring together these disjointed efforts around the existing Njala University partnership. With support from on-campus funding sources, three new courses were developed and piloted them this year. These courses will serve as the backbone for a global health scholar (GHS) certificate program offered through the Center for Global Studies. All courses are offered online so that students from both universities can take the courses together.

Subject-Specific Courses: Students will choose from a set of subject-specific courses currently under development using the partnership as a common theme. Each of these courses are taught by faculty with global health experience, and will provide different perspectives on what global health is (e.g. the implications of food security on diet and disease prevalence). To launch the program, three upper-level courses entered pilot stages in the 2015-2016 school year: 1) Tropical Epidemiology, which focuses on basic biostatistical and epidemiological methods for monitoring, control, and prevention of diseases found in the tropics. 2) Technology Innovation for Resource Limited Settings, which focuses on understanding designing for international standards, defining needs of a community, using locally available materials, low-tech but gamechanging innovations, considering sustainability implications in resource-limited settings, involving stakeholders and engaging the community and 3) Food Security for Health in LowIncome Countries, which focuses on understanding the importance of sufficient, safe, and nutritious food in economically under-developed locations. Each of these courses addresses ethical, social, and political concerns as part of the design process.

For this study, the focus is on the engineering course, Technology Innovation for Resource Limited Settings. The course objectives seek to help students identify community needs through observation techniques, investigate differences in manufacturing capacity, understand role of local context, and identify and address cultural issues that affect technology design and uptake. The assignments for the course include discussion posts, observational studies using videos captures at rural and global clinics, written papers on user-centered design and feasibility, economics, and local build considerations.

Online Learning Environment: Due to the unique needs of an international outreach partnership focused on bringing together students across courses, disciplines, and campuses, the program struggled identifying an online environment that facilitates such complex interactions. As a result, the program has collaborated with the College of Education and received funding to assist with the development and implementation of a collaborative online learning environment. The Learning Management System (LMS) for the program needed to be capable of delivering video lectures, serving as a repository of project data, and facilitating collaboration between scholars on both campuses. All of the courses for the certificate program operated in a unique online environment developed for the program. Locally developed and customizable, the Scholar platform is a next-generation LMS that takes advantage of the myriad of online tools that have developed outside of the educational arena (Facebook, Twitter, etc.) and the New Learning 
principles defined by education researchers ${ }^{1,2}$. Facilitating collaboration is a central focus of the LMS design, which is crucial to the international, interdisciplinary nature of the program.

Multimethod Intercultural Competence Assessment: Another distinctive feature of the program is the assessment approach. Although travel is a desirable part of any global program, not all students are able to travel, due to financial and other constraints. In the midst of various efforts to internationalize higher education, experts such as Deardorff and Terenzini \& Upcraft have advocated for the necessity to assess students' intercultural competence to measure effectiveness and to ensure the quality of such efforts ${ }^{3,4}$. Because virtual global learning is relatively new to internationalization practices and offers limited face-to-face contact, investigating whether virtual global learning experiences allow students to develop and enhance their intercultural competence is perhaps even more crucial. The team aims to leverage existing outcomes common to engineering and intercultural competencies to measure the success of the program and, in the future, to customize the assessment tools to make them efficient and effective measures of global competence.

Engineering competencies are defined by ABET whose accreditation sets the global standard for programs in applied science, computing, engineering, and engineering technology. Briefly, the competencies defined by ABET relating to non-technical skills are ability to function on a multidisciplinary team, ability to identify engineering problems, understanding of professional and ethical responsibility, communication skills, understand the impact of engineering solutions in a global and societal context, and knowledge of contemporary issues ${ }^{5}$.

The program's definition of intercultural competence is guided by literature, which describes intercultural knowledge and competence as "a set of cognitive, affective, and behavioral skills and characteristics that support effective and appropriate interaction in a variety of cultural contexts"6,7. With this recommendation in mind and in alignment with the program's goal, the study defines intercultural competence as "the ability to participate in a multicultural team-based learning environment effectively." Based on the definition of the project and literature recommendation for a multimethod, multi-perspective approach to intercultural competence, the instructors will conduct measurements of the certificate program over time using a multipronged approach that will include published surveys, rubrics for direct measurement of attitudes, knowledge, and skills as demonstrated in projects, observation of students' behavior in the online environment discussion boards using content analysis and social network analysis and an evaluation of students' perspectives related to their experiences ${ }^{8}$. These multiple mixed methods will better capture the complex phenomenon of students' growth in intercultural competence, addressing the following research questions:

1. Do students demonstrate an increase in intercultural competence as measured by survey instruments?

2. Do students demonstrate and perform effective intercultural competence as measured by their knowledge and skill in completing a project?

3. What are the characteristics of interaction and behavior related to intercultural competency in the online environment? 
4. What is the meaning of and what are the characteristics of the intercultural learning experience from the students' perspectives?

5. What is the relationship, if any, between online experiences and intercultural competence?

Communication is crucial to both engineering ability and intercultural competency, and therefore is the focus of the assessment designed for this project. Both sets of competencies also overlap in the importance of students' awareness of social and cultural context, especially with regard to problem solving. To this end, students' intercultural competence and their ability to participate in a multicultural team-based online-learning environment will be measured in order to determine the effectiveness of curriculum to affect intercultural competence.

First, students will be measured and compared to a control group, who are taking the online course, but not interacting with the students at Njala University, using three pre-post self-report survey instruments: the Intercultural Development Inventory, the Miville-Guzman UniversalityDiversity Scale, and the Ethnocentrism Scale. The Intercultural Development Inventory9 — a 50item questionnaire based on Milton Bennett's Developmental Model of Intercultural Sensitivity-looks at how people view and understand cultural differences between themselves and others. The Miville-Guzman Universality-Diversity Scale ${ }^{10}$ is a 15 -item questionnaire used to assess if students are interested in participating in diverse social and cultural activities, how much students value the impact of diversity on personal growth, and how comfortable students are with diverse individuals. The Ethnocentrism Scale is a 22-item questionnaire, which measures attitude towards cultures in different parts of the world ${ }^{11}$.

Second, students' performance in their course projects will be measured directly using the Association of American Colleges and Universities' (AAC\&U) VALUE rubric in intercultural competence. The AAC\&U provides a framework for assessing intercultural knowledge and competence in their VALUE rubric. The following knowledge, skills, and attitudes are outlined in the rubric: cultural self-awareness, knowledge of cultural worldview frameworks, empathy, verbal and nonverbal communication, curiosity, and openness. This rubric will be used to measure students' performance in projects for assessing performance in real-world intercultural situations ${ }^{12}$. This is increasingly recognized method of assessing students' competence, and supports project-based learning and team-based learning as effective instructional practices that provide students with opportunities to apply intercultural knowledge and skills in real-world intercultural contexts.

Third, this project examines learning processes in order to understand why students are or are not learning. Examining "learning processes, inputs, and context as well as outcomes will provide an insight toward what is happening to learning, which will result in a better understanding of how student learning improves through the program"13. This will be implemented by observing students' behavior via content analysis and social network analysis in the online environment discussion. Combining the use of content analysis to describe themes of content in students' interaction with social network analysis to describe the pattern of students' virtual interaction will better capture a rich description of learning processes in the online environment ${ }^{14}$. 
Fourth, students will take the Community of Inquiry Survey, which will allow us to determine if factors of online format - teaching presence, social presence, and cognitive presence - and intercultural competence progress exhibit a relationship ${ }^{15}$. A community of inquiry survey instrument has been used as a framework for effective online learning environments. A research team will also interview participants to further explore significance and characteristics of the intercultural learning experience based on purposeful sampling. The purposeful sampling may include typical cases or atypical cases based on the scores of the survey instruments.

\section{Preliminary results}

For the pilot stage of the project, ongoing now, students enrolled in the Technology Innovation for Resource Limited Settings will be recruited to complete a survey. The survey consists of thirty seven items, of which twenty two are from the Ethnocentrism Scale and fifteen are from the Miville-Guzman Universality-Diversity Scale. The survey is rated based on the Likert scale ranging from (1) 'strongly disagree' to (6) 'strongly agree.' Individual students' scores for each of these two scales are calculated separately. The possible scores for both the Ethnocentrism Scale and the Miville-Guzman Universality-Diversity Scale in Table 1 range 1 to 6. A low score in the Ethnocentrism Scale represents less ethnocentric and open and flexible attitude towards cultures in different parts of the world. A high score in the Miville-Guzman UniversalityDiversity Scale represents a high degree of interest, value, and comfort in interacting with diverse individuals and activities.

The AAC\&U Rubric for Intercultural Knowledge and Competence will be used to assess assignments at the beginning and end of the certificate to determine any shifts in competence knowledge, skills, and attitudes. In the pilot study, students are being assessed on the AAC\&U rubric to set a baseline for performance and test the alignment of assignments with the rubric tool. For the categories of "knowledge of cultural frameworks" and "empathy" on the rubric, we have seen shifts from developing (1) to Milestones (3) within one course based on analysis of two discussion posts during the semester. Students were asked to post and respond to two other posts for each assignment. The pilot study included 16 students and $12(75 \%)$ achieved a 3 rating on the final discussion post compared to $1(6 \%)$ on the first discussion post. These assessments were performed separate from grading for the course. The prompts are included in Appendix A.

This multi-pronged approach to global health education will provide a unique, immersive experience for students who are committed to solving problems in resource-limited regions as well as foster entrepreneurial expertise to support the delivery of developed solutions.

\section{References}

1. Mary Kalantzis \& Bill Cope (2012). New Learning: Elements of a Science of Education.

2. http://info.cgscholar.com/ 
3. Deardorff, D. K. (2006). Identification and Assessment of Intercultural Competence as a Student Outcome of Internationalization. Journal of Studies in International Education, 10(3), 241-266. http://doi.org/10.1177/1028315306287002

4. Terenzini, P., \& Upcraft, M. (1996). Assessing programs and service outcomes. In M. L. Upcraft (Ed.), Assessment in student affairs : a guide for practitioners / (1st ed., pp. 217-239). San Francisco : JosseyBass Publishers.

5. Volkwein, J. F., Lattuca, L. R., Terenzini, P. T., Strauss, L. C., \& Sukhbaatar, J. A. V. Z. A. N. (2004). Engineering change: A study of the impact of EC2000. International Journal of Engineering Education, 20(3), 318-328.

6. Paige, R. M., Jacobs-Cassuto, M, Yershova, Y. A., et al. (2003) Assessing Intercultural Sensitivity: an Empirical. Analysis of the Hammer and Bennet Intercultural Development Inventory. International Journal of Intercultural Relations, 27, 467-486.

7. Fantini, A. (2009). Assessing Intercultural Competence: Issues and Tools. In D. Deardorff (Ed.), The SAGE Handbook of Intercultural Competence (pp. 456-476). Thousand Oaks, Calif: SAGE Publications.

8. Deardorff, D. K. (2011). Assessing intercultural competence. New Directions for Institutional Research, 2011(149), 65-79.

9. Hammer, M. R., Bennett, M. J., \& Wiseman, R. (2003). Measuring intercultural sensitivity: The intercultural development inventory. International Journal of Intercultural Relations, 27(4), 421-443.

10. Fuertes, J. N., Miville, M. L., Mohr, J. J., Sedlacek, W. E., \& Gretchen, D. (2000). Factor Structure and Short Form of the Miville-Guzman Universality-Diversity Scale. Measurement \& Evaluation in Counseling \& Development (American Counseling Association), 33(3), 157.

11. Neuliep, J. W. (2003). Assessing the Reliability and Validity of the Generalized Ethnocentrism Scale. In Conference Papers -- International Communication Association (pp. 1-25). International Communication Association.

12. Deardorff, D. K. (2015). Demystifying outcomes assessment for international educators : a practical approach. Sterling, Virginia: Stylus Publishing.

13. Suskie, L. A. (2009). Assessing student learning : a common sense guide / (2nd ed.). San Francisco, CA : Jossey-Bass.

14. De Laat, M., Lally, V., Lipponen, L., \& Simons, R.-J. (2007). Online Teaching in Networked Learning Communities: A Multi-Method Approach to Studying the Role of the Teacher. Instructional Science: An International Journal of the Learning Sciences, 35(3), 257-286.

15. Arbaugh, J. B., Cleveland-Innes, M., Diaz, S. R., Garrison, D. R., Ice, P., Richardson, J. C., \& Swan, K. P. (2008). Developing a community of inquiry instrument: Testing a measure of the Community of Inquiry framework using a multi-institutional sample. The Internet and Higher Education, 11(3-4), 133-136. 


\section{Instructions}

\section{Week 1 Discussion}

Write a discussion post about the topic below. Posts should follow the rubric below and be roughly 200-500 words.

Infectious diseases are communicable, but could the following also be communicable? Why or why not?

- Dietary changes

- A lack of physical activity

- Automobile related issues

- $\quad$ Smoking

- Stress

- Urbanization

\section{Where to Submit}

The Week 1 Discussion Activity will take place in Scholar.

- Log into your Scholar account and enter the Class Community.

- Make a new Update. Use the title "Week 1: YOUR NAME."

- Comment on at least 2 of your classmates' Week 1 Updates in Scholar.

- If you need help, be sure to check out the PDF A Quick Introduction to Scholar or the Scholar Tutorials.

\section{Evaluation}

The discussion activity is worth 50 points. The following rubric will be used to evaluate your performance.

\begin{tabular}{|c|c|c|c|c|c|}
\hline Criteria & Excellent & Above Average & Sufficient & Developing & Needs Improvement \\
\hline Content & $\begin{array}{l}\text { (20-18 points) } \\
\text { Shares thoughts, ideas, or } \\
\text { opinions. } \\
\text { Specific details are offered to } \\
\text { support the views expressed } \\
\text { in the post (there is evidence } \\
\text { to show this isn't just "off the } \\
\text { top of your head"). } \\
\text { Has a "So what?" theme, } \\
\text { lesson, or specific point that } \\
\text { attracts readers' attention; it } \\
\text { also addresses all the } \\
\text { questions posed in the } \\
\text { exercise but goes beyond just } \\
\text { answering them to reflect on } \\
\text { larger themes. } \\
\text { Demonstrates understanding } \\
\text { of the topic. }\end{array}$ & $\begin{array}{l}\text { (17-15 points) } \\
\text { Shares thoughts, ideas, or } \\
\text { opinions. } \\
\text { Details are offered to support } \\
\text { the views expressed in the post } \\
\text { (there is evidence to show this } \\
\text { isn't just "off the top of your } \\
\text { head"). } \\
\text { Has a "So what?" theme, or } \\
\text { lesson; addresses all questions } \\
\text { posed in the exercise. } \\
\text { Demonstrates understanding of } \\
\text { the topic. }\end{array}$ & $\begin{array}{l}\text { (14-12 points) } \\
\text { Shares thoughts, ideas, or } \\
\text { opinions. } \\
\text { The opening part of the post } \\
\text { introduces the main point. } \\
\text { Details are offered to support } \\
\text { views expressed in the post, } \\
\text { but they may be vague or the } \\
\text { connections not completely } \\
\text { clear. } \\
\text { Has a point; has something } \\
\text { to do with the questions } \\
\text { posed. } \\
\text { Shows some understanding } \\
\text { of the topic. }\end{array}$ & $\begin{array}{l}\text { (11-9 points) } \\
\text { Shares a thought, idea, or opinion. } \\
\text { The opening part of the post } \\
\text { introduces the main point. } \\
\text { Limited details are offered to } \\
\text { support the views expressed in the } \\
\text { post. } \\
\text { Point of post is unclear; does not } \\
\text { relate to the questions. } \\
\text { Shows some understanding of the } \\
\text { topic. }\end{array}$ & $\begin{array}{l}\text { (8-0 points) } \\
\text { Main point is not clearly } \\
\text { introduced. } \\
\text { Lacks supporting details. } \\
\text { Point of post is unclear; does } \\
\text { not relate to the questions. } \\
\text { Post does not reveal an } \\
\text { understanding of the topic. }\end{array}$ \\
\hline
\end{tabular}




\begin{tabular}{|c|c|c|c|c|c|}
\hline & $\begin{array}{l}\text { Concise with a specific focus } \\
\text { (4-5 paragraphs). } \\
\text { Opening grabs the reader's } \\
\text { attention while introducing } \\
\text { the point of the post. } \\
\text { Positive tone engages the } \\
\text { reader. } \\
\text { Spelling, punctuation, and } \\
\text { capitalization are correct. }\end{array}$ & $\begin{array}{l}\text { Concise with a focus (3-4 } \\
\text { paragraphs) } \\
\text { Opening grabs the reader's } \\
\text { attention while introducing the } \\
\text { point of the post but perhaps } \\
\text { not as strongly as the style in an } \\
\text { "A" posting. } \\
\text { Positive tone engages the } \\
\text { reader. } \\
\text { Spelling, punctuation, and } \\
\text { capitalization are largely } \\
\text { correct. }\end{array}$ & $\begin{array}{l}\text { Post is short (1-2 } \\
\text { paragraphs) with a focus. } \\
\text { Post has a positive tone. } \\
\text { Spelling, punctuation, and } \\
\text { capitalization are largely } \\
\text { correct. }\end{array}$ & $\begin{array}{l}\text { Post is short (1 paragraph) and } \\
\text { may or may not have a focus. } \\
\text { Post has a positive tone. } \\
\text { Spelling, punctuation, and } \\
\text { capitalization contain mistakes. }\end{array}$ & $\begin{array}{l}\text { Post is short (1 paragraph) and } \\
\text { lacks focus. } \\
\text { Tone may not be appropriate. } \\
\text { Spelling, punctuation, and } \\
\text { capitalization contain numerous } \\
\text { mistakes. }\end{array}$ \\
\hline Reply & $\begin{array}{l}\text { (10-9 points) } \\
\text { Reply refers to another } \\
\text { person's post, is constructive } \\
\text { and thoughtful, adds a new } \\
\text { idea (either by refining post's } \\
\text { idea, disagreeing with it, } \\
\text { building on it, etc.), has a } \\
\text { point, and uses appropriate } \\
\text { spelling, punctuation, and } \\
\text { grammar. }\end{array}$ & $\begin{array}{l}\text { (8-7 points) } \\
\text { Reply refers to post, is } \\
\text { constructive and thoughtful, has } \\
\text { a point, and uses appropriate } \\
\text { spelling, punctuation, and } \\
\text { grammar. }\end{array}$ & $\begin{array}{l}\text { (6-5 points) } \\
\text { Reply refers to post, has a } \\
\text { point, and uses mostly } \\
\text { appropriate spelling, } \\
\text { punctuation, and grammar. }\end{array}$ & $\begin{array}{l}\text { (4-3 points) } \\
\text { Reply refers to post and contains } \\
\text { spelling and grammatical } \\
\text { mistakes. }\end{array}$ & $\begin{array}{l}\text { (2-0 points) } \\
\text { Reply is not connected with the } \\
\text { post and contains numerous } \\
\text { spelling and grammatical } \\
\text { mistakes. }\end{array}$ \\
\hline
\end{tabular}

The Week 6 Discussion Activity will take place in Scholar.

- Log into your Scholar Account and enter the Class Community.

- Make a new Update. Use the title "Week 6: YOUR NAME"

- Comment on at least two of your classmates' Week 6 Updates in Scholar.

- If you need help, be sure to check out the PDF "A Quick Introduction to Scholar" or the Scholar Tutorials.

Discussion Prompt:

1. Watch WHO: The Power and Potential of Medical Devices (YouTube).

2. Pick one of the devices that you saw/were mentioned in the video and write a discussion post on the feasibility for its use in West Africa using the HTA framework.

-Safety

-Clinical effectiveness

-Economic considerations

-Ethical issues

-Acceptability to patients

-Education needed to support device 


\begin{tabular}{|c|c|c|c|c|c|}
\hline Criteria & Excellent & Above Average & Sufficient & Developing & Needs Improvement \\
\hline Content & $\begin{array}{l}\text { (20-18 points) } \\
\text { Shares thoughts, ideas, or } \\
\text { opinions. } \\
\text { Specific details are offered to } \\
\text { support the views expressed } \\
\text { in the post (there is evidence } \\
\text { to show this isn't just "off the } \\
\text { top of your head"). } \\
\text { Has a "So what?" theme, } \\
\text { lesson, or specific point that } \\
\text { attracts readers' attention; it } \\
\text { also addresses all the } \\
\text { questions posed in the } \\
\text { exercise but goes beyond just } \\
\text { answering them to reflect on } \\
\text { larger themes. } \\
\text { Demonstrates understanding } \\
\text { of the topic. }\end{array}$ & $\begin{array}{l}\text { (17-15 points) } \\
\text { Shares thoughts, ideas, or } \\
\text { opinions. } \\
\text { Details are offered to support } \\
\text { the views expressed in the post } \\
\text { (there is evidence to show this } \\
\text { isn't just "off the top of your } \\
\text { head"). } \\
\text { Has a "So what?" theme, or } \\
\text { lesson; addresses all questions } \\
\text { posed in the exercise. } \\
\text { Demonstrates understanding of } \\
\text { the topic. }\end{array}$ & $\begin{array}{l}\text { (14-12 points) } \\
\text { Shares thoughts, ideas, or } \\
\text { opinions. } \\
\text { The opening part of the post } \\
\text { introduces the main point. } \\
\text { Details are offered to support } \\
\text { views expressed in the post, } \\
\text { but they may be vague or the } \\
\text { connections not completely } \\
\text { clear. } \\
\text { Has a point; has something } \\
\text { to do with the questions } \\
\text { posed. } \\
\text { Shows some understanding } \\
\text { of the topic. }\end{array}$ & $\begin{array}{l}\text { (11-9 points) } \\
\text { Shares a thought, idea, or opinion. } \\
\text { The opening part of the post } \\
\text { introduces the main point. } \\
\text { Limited details are offered to } \\
\text { support the views expressed in the } \\
\text { post. } \\
\text { Point of post is unclear; does not } \\
\text { relate to the questions. } \\
\text { Shows some understanding of the } \\
\text { topic. }\end{array}$ & $\begin{array}{l}\text { (8-0 points) } \\
\text { Main point is not clearly } \\
\text { introduced. } \\
\text { Lacks supporting details. } \\
\text { Point of post is unclear; does } \\
\text { not relate to the questions. } \\
\text { Post does not reveal an } \\
\text { understanding of the topic. }\end{array}$ \\
\hline Style & $\begin{array}{l}\text { (10-9 points) } \\
\text { Concise with a specific focus } \\
\text { (4-5 paragraphs). } \\
\text { Opening grabs the reader's } \\
\text { attention while introducing } \\
\text { the point of the post. } \\
\text { Positive tone engages the } \\
\text { reader. } \\
\text { Spelling, punctuation, and } \\
\text { capitalization are correct. }\end{array}$ & $\begin{array}{l}\text { (8-7 points) } \\
\text { Concise with a focus (3-4 } \\
\text { paragraphs) . } \\
\text { Opening grabs the reader's } \\
\text { attention while introducing the } \\
\text { point of the post but perhaps } \\
\text { not as strongly as the style in an } \\
\text { "A" posting. } \\
\text { Positive tone engages the } \\
\text { reader. } \\
\text { Spelling, punctuation, and } \\
\text { capitalization are largely } \\
\text { correct. }\end{array}$ & $\begin{array}{l}\text { (6-5 points) } \\
\text { Post is short (1-2 } \\
\text { paragraphs) with a focus. } \\
\text { Post has a positive tone. } \\
\text { Spelling, punctuation, and } \\
\text { capitalization are largely } \\
\text { correct. }\end{array}$ & $\begin{array}{l}\text { (4 points) } \\
\text { Post is short (1 paragraph) and } \\
\text { may or may not have a focus. } \\
\text { Post has a positive tone. } \\
\text { Spelling, punctuation, and } \\
\text { capitalization contain mistakes. }\end{array}$ & $\begin{array}{l}\text { (3-0 points) } \\
\text { Post is short ( } 1 \text { paragraph) and } \\
\text { lacks focus. } \\
\text { Tone may not be appropriate. } \\
\text { Spelling, punctuation, and } \\
\text { capitalization contain numerous } \\
\text { mistakes. }\end{array}$ \\
\hline Reply & $\begin{array}{l}\text { (10-9 points) } \\
\text { Reply refers to another } \\
\text { person's post, is constructive } \\
\text { and thoughtful, adds a new } \\
\text { idea (either by refining post's } \\
\text { idea, disagreeing with it, } \\
\text { building on it, etc.), has a } \\
\text { point, and uses appropriate } \\
\text { spelling, punctuation, and } \\
\text { grammar. }\end{array}$ & $\begin{array}{l}\text { (8-7 points) } \\
\text { Reply refers to post, is } \\
\text { constructive and thoughtful, has } \\
\text { a point, and uses appropriate } \\
\text { spelling, punctuation, and } \\
\text { grammar. }\end{array}$ & $\begin{array}{l}\text { (6-5 points) } \\
\text { Reply refers to post, has a } \\
\text { point, and uses mostly } \\
\text { appropriate spelling, } \\
\text { punctuation, and grammar. }\end{array}$ & $\begin{array}{l}\text { (4-3 points) } \\
\text { Reply refers to post and contains } \\
\text { spelling and grammatical } \\
\text { mistakes. }\end{array}$ & $\begin{array}{l}\text { (2-0 points) } \\
\text { Reply is not connected with the } \\
\text { post and contains numerous } \\
\text { spelling and grammatical } \\
\text { mistakes. }\end{array}$ \\
\hline
\end{tabular}

